
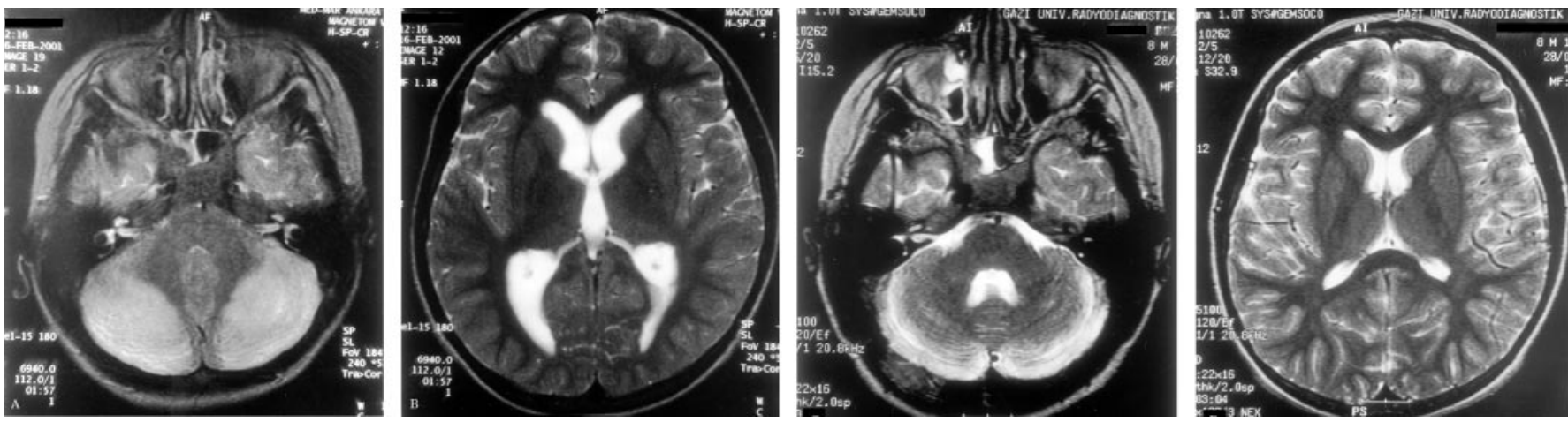

Figure 1. MRI on admission revealing obstructive hydrocephalus (A) and high intensity on T2-weighted imaging in both cerebellar hemispheres (B). Follow-up MRI study on 14th day of treatment showing normal ventricular size (C) and decreased cerebellar hyperintense signals on T2-weighted image and mild atrophy of the cerebellum (D).

\section{Acute cerebellitis with hydrocephalus}

F. Dogulu, MD; A. Onk, MD; M. Kaymaz, MD; O. Kardes, $M D$; and M.K. Baykaner, MD

An 8-year-old boy presented with headache, nausea, vomiting, and gait and limbs ataxia 1 week after a respiratory tract infection. MRI showed obstructive hydrocephalus ( figure 1A) and bilateral cerebellar swelling with hyperintense signals on T2weighted imaging (see figure 1B). CSF studies showed mild pleocytosis. The diagnosis was acute cerebellitis. Following treat-

From the Department of Neurosurgery (Drs. Dogulu, Onk, Kaymaz, and Kardes) and Division of Pediatric Neurosurgery (Dr. Baykaner), School of Medicine, University of Gazi, Ankara, Turkey.

Received July 25, 2002. Accepted in final form January 30, 2003.

Address correspondence and reprint requests to Dr. F. Dogulu, Resit Galip Cad. 72/6, G.O.P. Ankara 06700, Turkey; e-mail: fdogulu@hotmail.com ment with acyclovir and corticosteroids, the clinical and radiologic signs resolved (figure 2). The patient made an uneventful recovery, with elimination of neurologic deficit.

Cerebellitis is an inflammatory syndrome of cerebellar dysfunction that may result from viral or autoimmune etiologies. ${ }^{1}$ MRI shows hyperintense signals of cerebellar gray matter in T2weighted sequences, which is a strong indication of a diagnosis of acute cerebellitis. ${ }^{2}$ Resolution of the hyperintense areas in the cerebellar cortex can be associated with recovery from the clinical manifestations, although MRI shows mild cerebellar atrophy, as in the current case.

1. Levy ES, Harris AE, Omalu BI, Hamilton RL, Branstetter BF IV, Pollack IF. Sudden death from fulminant acute cerebellitis. Pediatr Neurosurg 2001;35:24-28.

2. Montenegro MA, Santos SL, Li LM, Cendes F. Neuroimaging of acute cerebellitis. J Neuroimag 2002;12:72-74. 


\section{Neurology}

Acute cerebellitis with hydrocephalus

F. Dogulu, A. Onk, M. Kaymaz, et al.

Neurology 2003;60;1717

DOI 10.1212/01.WNL.0000064168.64413.FF

This information is current as of May 27, 2003

\section{Updated Information \& Services}

\section{References}

Citations

Subspecialty Collections

Permissions \& Licensing

Reprints including high resolution figures, can be found at: http://n.neurology.org/content/60/10/1717.full

This article cites 2 articles, 0 of which you can access for free at: http://n.neurology.org/content/60/10/1717.full\#ref-list-1

This article has been cited by 1 HighWire-hosted articles: http://n.neurology.org/content/60/10/1717.full\#\#otherarticles

This article, along with others on similar topics, appears in the following collection(s):

All Imaging

http://n.neurology.org/cgi/collection/all_imaging

All Infections

http://n.neurology.org/cgi/collection/all_infections

MRI

http://n.neurology.org/cgi/collection/mri

Pediatric headache

http://n.neurology.org/cgi/collection/pediatric_headache

Viral infections

http://n.neurology.org/cgi/collection/viral_infections

Information about reproducing this article in parts (figures,tables) or in its entirety can be found online at:

http://www.neurology.org/about/about_the_journal\#permissions

Information about ordering reprints can be found online:

http://n.neurology.org/subscribers/advertise

Neurology ${ }^{\circledR}$ is the official journal of the American Academy of Neurology. Published continuously since 1951, it is now a weekly with 48 issues per year. Copyright . All rights reserved. Print ISSN: 0028-3878. Online ISSN: 1526-632X.

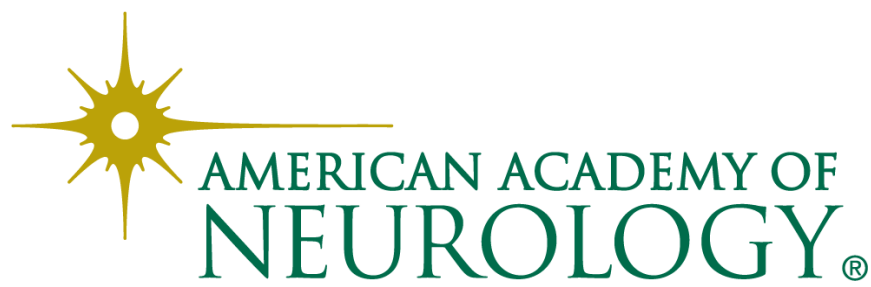

